\title{
TERRITORIAL DEVELOPMENT ASSESSMENT IN LATVIA
}

\author{
Aleksejs Nipers, Irina Pilvere, Zane Bulderberga \\ Latvia University of Agriculture \\ Aleksejs.Nipers@1lu.lv; Irina.Pilvere@1lu.lv; Zane.Bulderberga@1lu.lv
}

\begin{abstract}
It is important for every country that its territory develops evenly and in a balanced way. In the European Union (EU), a special focus is placed on the development of rural territories, as predominantly rural regions in the EU represent $57 \%$ of the territory and $24 \%$ of the population. In Latvia, the development of rural territories depends on economic growth in the key industries for the rural areas - agriculture and forestry, and logging that contributed to $4.3 \%$ of GDP and employed $9.5 \%$ of the labour force in 2011 . Therefore, the research aim is to perform an assessment of the administrative territories of Latvia. The research analysed the municipalities of Latvia in terms of population and change in the population as well as in terms of revenue and income and change in the revenue and income. The research found that in Latvia the best economic performance was demonstrated by the municipalities with a population in the range of 8-12 thousand. In the period $2004-2014$, the number of residents decreased by more than $20 \%$ in 49 municipalities of Latvia. Such municipalities are located far away from the capital city, and poor economic performance indicators with a prevailing primary sector were typical of the municipalities. The municipalities with higher tax revenue had larger populations, which increased in the period of analysis, and such municipalities are located in the vicinity of Riga and high economic performance indicators were characteristic of them.
\end{abstract}

Key words: administrative territories, development, indicators.

\section{Introduction}

The problems of development and assessment of territories have been urgent both to policy makers and to researchers. However, still there is no single approach and methodology developed in the world and Latvia with regard to what principles and indicators have to be employed to assess the development level and pace of a particular territory (a region, a municipality, a rural territory or a town or city) as well as the influencing factors. L.G. Bellù (2011) emphasises that territorial development means the development of a specific region (space) achievable by exploiting the specific socio-economic, environmental and institutional potential of the area, and its relationships with external subjects. The problem of development of rural territories is of great importance in the EU, as predominantly rural regions in the EU represent $57 \%$ of the territory and $24 \%$ of the population. In 2009 , they generated $17 \%$ of the total gross value added and $22 \%$ of the employment (European Commission, 2011). In land use terms, rural areas represent $93 \%$ of the EU-27 territory, with $20 \%$ of the population living in predominantly rural areas and $38 \%$ in significantly rural areas (ECORYS Nederland BV, 2010). Rural areas still account for almost half the world's population, but after 2020, it is expected that rural population will begin to decline, especially in China and India (Eppler, Fritsche, \& Laaks, 2015). M. Ambrosio-Albalá and J.Bastiaensen (2010) stress that rural studies have broadened their focus from merely technical and economic agrarian issues to a wider array of topics, inspired by disciplines such as sociology, politics, anthropology, ecology and history. The free circulation of capital in the newly expanded trading spaces and the conversion processes that local areas are obliged to undertake together with technological innovations give rise to new maps of production with their inevitable outcome of losses and gains (Boisier, 2005). Rural areas have, for long generations, provided most of the food, fibre, timber, firewood, water and minerals upon which an increasingly urbanised Europe depends. They have provided also the skills with which these resources are gathered, processed and transported. There is currently growing worldwide pressure on resources of all kinds (Dower, 2013). A research study by ESPON (2013) has found that three key issues for territorial development are: 1) the need to better understand patterns of differentiation, between different kinds of rural areas; 2) the nature of the different opportunities for development which each of them faces; 3) the way in which such opportunities depend upon and may be strengthened by interaction between rural and urban areas. I. Dunmade (2014) also has a similar opinion that provincial/federal policies and incentives that encourage collaboration are also essential for successful voluntary rural-urban communities' partnerships. It is important to study the impacts of political differences and demographic changes on rural-urban regional economic partnership. The changes in economic policies have resulted in changes in economic activities in some localities, caused demographic changes in some municipalities and consequent reduction in revenue generations and attendant difficulty in maintaining infrastructural services at the local level.

Not only in Latvia but also in the entire Europe rural territories face depopulation. In Latvia, approximately $30 \%$ of the population live in rural areas; of them, about $20 \%$ may be regarded as rural residents in terms of lifestyle and economic base (Vitola, 2013). In Latvia, the development of rural territories depends 
on economic growth in the key industries for the rural areas - agriculture and forestry, and logging that contributed to $4.3 \%$ of GDP and employed 81.9 thousand residents or $9.5 \%$ of the labour force in the country in 2011 (Zemkopibas ministrija, 2016). The research aim is to perform an assessment of the administrative territories of Latvia.

To achieve the aim, the following specific research tasks were set: 1) to analyse the municipalities of Latvia in terms of population and change in the population; 2) to assess the municipalities of Latvia in terms of revenue and income as well as change in the revenue and income. The object of the research is municipalities in Latvia.

\section{Materials and Methods}

The research employed the administrative division of the territory of Latvia that existed at the beginning of 2015 - 9 cities of national significance (with more than 25000 residents) and 110 municipalities (Administrativvo teritoriju..., 2008). In view of the 2009 administrative and territorial reform in Latvia, the available data on civil parishes were recalculated into the data for municipalities (population, personal income tax (PIT) revenue). Indicators expressed in Latvian lats (LVL) were converted into euros based on the official exchange rate set by the Bank of Latvia: 1 EUR $=0.702804$ LVL (LB, 2013). Since municipalities are large territorial units, for methodological purposes the research applied the approach of grouping according to selected criteria to perform a very detailed analysis. Such an approach allows sufficiently clearly identify associations through analysing a broad spectrum of indicators; yet it does not allow precisely determine the quantitative effects of the indicators.

The present research analysed 110 municipalities, employing indicators showing the demographic situation, economic growth and available resources. A comparative analysis of the municipalities was performed by grouping the municipalities according to significant indicators of their development and growth: the number of residents in 2014 and its change since 2004 as well as the amount of tax revenue collected by the local governments - PIT revenue per capita in 2013 and change in the PIT revenue since 2004. The selected indicators reflected both the current situation and the trend since the base year (2004). The research used data of the Central Statistical Bureau of Latvia (CSB), the State Regional Development Agency (SRDA) and the State Land Service (SLS). The present research analysed the amounts of support payments disbursed by the Rural Support Service (RSS), which is responsible for the administration of the EU's CAP and Common Fisheries Policy support payments that are funded by the European
Agricultural Guarantee Fund (EAGF), the European Agricultural Fund for Rural Development (EAFRD) and the European Fisheries Fund (EFF). The amounts of funding disbursed in municipalities by other funds - the European Regional Development Fund (ERDF), the European Social Fund (ESF) and the Cohesion Fund (CF) were analysed as well. Lursoft data on top 20 enterprises in terms of turnover, which were grouped into three categories, were used for business characteristics. The primary sector is comprised of agriculture, hunting, forestry, fisheries and mining. The present research classifies the primary sector into three categories: agriculture, forestry and other industries. The secondary sector consists of manufacturing, electricity supply, gas supply, water supply and construction. The research classifies this sector into the following categories: food production, wood processing that includes such economic activities as 1) sawing, planning and impregnation, 2) manufacture of carpentry and joinery products, 3) manufacture of furniture, 4) manufacture of wood packaging etc., as well as other manufacturing industries. The tertiary or services sector - enterprises providing various services for businesses and households - are classified into two broad categories: private services (wholesale and retail trade, construction, etc.) and public services (utilities, education, health care, electricity production, waste management etc.). Energy production belongs to the category of public services (LLU, 2015).

\section{Results and Discussion}

1. Assessment of territories in Latvia in terms of population and change in the population

According to the research study by ECORYS Nederland BV (2010), the key barriers reported through case studies to growth in rural areas are primarily: 1) demographic evolutions and migration (loss of young people and ageing); 2) infrastructure and accessibility; 3 ) the sectoral structure of the economy. Accordingly, one of the most frequently employed indicators to characterise a municipality in Latvia is the number of residents. Despite the fact that one of the objectives of the 2009 administrative and territorial reform was to establish maximally similar administrative territories in terms of population size, currently large disparities in population size are observed across the municipalities. An increase in indicator values reflects successful development in the municipalities, whereas low or negative indicator values indicate potential stagnation and the lack of development. The research grouped the municipalities into five groups by population size - there were 37 municipalities with a population of less than 4000,30 municipalities with a population ranging from 4000 to 8000,23 - with a population ranging from 8000 to 12000 and $20-$ with a population of more than 
12000 . The average values of influencing factors were calculated for each group (Table 1). After grouping the municipalities by population size, one can conclude that: 1) in the municipalities with a larger population, incomes and wages, and salaries of their residents were higher as well as the turnover of enterprises was considerably higher, whereas in the municipalities with a population of more than 20000 the mentioned indicators tended to decrease; 2) the best economic performance indicators if measured per capita were specific to the municipalities with a population ranging from 8000 to 12000 . In the mentioned municipalities, the investment level and the turnover of enterprises were higher, and the proportion of public sector employees was lower; 3) the primary sector prevailed in the municipalities with a small population - the UAA and the forest area were large, whereas the total amount of RSS-administered support payments was relatively small in the municipalities, which indicated ineffective land management in such municipalities. Similar trends may be also observed elsewhere in Europe - the key economic sectors are currently 1) agriculture; 2) tourism; 3) food and drink and 4) construction. Within the first three sectors, diversification of regional economies is considered key in driving growth (ECORYS Nederland BV, 2010).

In the eyes of residents, the attractiveness of a territory is characterised by population changes in a long-term - the present research analysed the situation in a 10 -year period. The municipalities were grouped into three groups: the first group consisted of 49 municipalities where the population decreased by more than $20 \%$ in 2014 compared with 2004; the second group included 43 municipalities where the population decreased by less than $20 \%$, and the third group had 18 municipalities, in which their populations increased (Table 2). Analysing the situation in the

Characteristics of the municipalities of Latvia grouped by population size in 2014

Table 1

\begin{tabular}{|c|c|c|c|c|c|}
\hline \multirow[b]{2}{*}{ Indicators } & \multicolumn{5}{|c|}{ Population in the municipality } \\
\hline & $\leq 4000$ & $\begin{array}{c}4000- \\
8000\end{array}$ & $\begin{array}{c}8000 \\
-12000\end{array}$ & $\begin{array}{c}12000- \\
20000\end{array}$ & $>20000$ \\
\hline Number of municipalities in a group & 37 & 30 & 19 & 10 & 14 \\
\hline Change in the population in 10 years & 0.81 & 1.02 & 0.96 & 1.14 & 0.88 \\
\hline Distance to Riga (average for the group), $\mathrm{km}$ & 158 & 123 & 99 & 135 & 110 \\
\hline Boundary municipalities of Riga & 0 & 3 & 4 & 2 & 2 \\
\hline Pieriga municipalities & 2 & 9 & 7 & 3 & 3 \\
\hline Boundary municipalities of republican cities & 3 & 6 & 6 & 2 & 5 \\
\hline PIT revenue per capita, EUR & 341 & 396 & 471 & 438 & 411 \\
\hline Increase in PIT revenue per capita, $\%$ & 2.05 & 1.98 & 1.81 & 1.77 & 1.63 \\
\hline Average monthly wage and salary, EUR & 562 & 640 & 709 & 646 & 656 \\
\hline Foreign investment per capita, EUR & 136 & 747 & 1489 & 1751 & 1458 \\
\hline ERDF, ESF, CF funding per capita, EUR & 1693 & 2477 & 1554 & 1205 & 1067 \\
\hline Local government equalisation funding per capita, EUR & 889 & 799 & 271 & 234 & 642 \\
\hline Managed UAA per capita, ha & 3.90 & 2.91 & 1.57 & 1.17 & 1.91 \\
\hline Land quality, points & 37 & 37 & 38 & 36 & 40 \\
\hline Forest area per capita, ha & 5.58 & 4.32 & 2.88 & 2.41 & 2.25 \\
\hline Amount of EAGF, EAFRD, EFF funding per capita, EUR & 3431 & 2704 & 2205 & 1182 & 951 \\
\hline \multicolumn{6}{|l|}{ Turnover of top 20 enterprises: } \\
\hline Total turnover per capita, EUR & 5195 & 7460 & 9388 & 13650 & 8840 \\
\hline Primary production, turnover per capita, EUR & 1886 & 1372 & 804 & 367 & 687 \\
\hline Secondary production, turnover per capita, EUR & 1387 & 2194 & 3390 & 3181 & 2328 \\
\hline Services sector, turnover per capita, EUR & 2076 & 4056 & 5500 & 10397 & 5952 \\
\hline Total support payments disbursed by the RSS, EUR & 4747 & 4703 & 5659 & 5780 & 6313 \\
\hline Area-based support payments, EUR & 2811 & 3085 & 3519 & 3842 & 3837 \\
\hline
\end{tabular}

Source: authors' calculations based on LLU, 2014, 2015, CSB, 2016a, 2016b, SRDA, 2016, Riga, 2016, RSS, 2016a, 2016b, 2016c, 2016d, SLS, 2014, LV, 2013, Lursoft, 2016. 
aspect of population change, a very explicit trend may be observed - the populations of municipalities located in the vicinity of Riga increased in size. Since 2004, the mentioned municipalities have had considerably greater PIT revenue increases, a higher average wage and salary and, consequently, higher per-capita PIT revenues paid to the local government. Entrepreneurship in the municipalities has been considerably more active - higher investment levels and a higher total turnover of enterprises per capita (more than twice higher than in other municipalities). The highest turnover was reported in the services' sector (EUR 13809 per capita or three times higher than the average in the country); the turnover of secondary sector enterprises was also high - 1.7 times higher than the average in the country. However, the sizes of primary resources were the smallest - the managed UAA (0.86 ha per capita) as well as the forest area (1.28 ha per capita) were very small and the quality of land was low (on average, 35 points); consequently, the amounts of support payments disbursed by the RSS were the smallest. A characteristic feature of the mentioned municipalities was the amount of absorbed agriculture-related EU funding per capita it was up to two times lower than in other groups of municipalities. Positive development was also indicated by the fact that the mentioned municipalities did not receive subsidies from the Local Government Equalisation Fund; they made contributions to the Fund - EUR 394 per capita. An opposite situation was observed in 49 municipalities where the population decreased by more than $20 \%$. The municipalities are located further away from Riga and their economic situation is poorer: low wages and salaries, small amounts of PIT revenue paid to the local government, small investments and a lower turnover of enterprises, where a large role is played by the primary sector. The municipalities received large subsidies from the Local Government Equalisation Fund. Compared with other groups of municipalities, the municipalities

Table 2

The municipalities grouped by change in population size in Latvia in the period $2004-2014$

\begin{tabular}{|c|c|c|c|}
\hline \multirow{2}{*}{ Indicators } & \multicolumn{3}{|c|}{ Change in the population } \\
\hline & $<-20 \%$ & $\geq-20 \%-0 \%$ & $\geq 0 \%$ \\
\hline Number of municipalities in a group & 49 & 43 & 18 \\
\hline Change in the population in 10 years & 6211 & 11214 & 10647 \\
\hline Distance to Riga (average for the group), $\mathrm{km}$ & 181 & 110 & 40 \\
\hline Boundary municipalities of Riga & 0 & 0 & 11 \\
\hline Pieriga municipalities & 0 & 7 & 17 \\
\hline Boundary municipalities of republican cities & 3 & 10 & 9 \\
\hline PIT revenue per capita, EUR & 305 & 405 & 624 \\
\hline Increase in PIT revenue per capita, $\%$ & 1.55 & 1.73 & 3.31 \\
\hline Average monthly wage and salary, EUR & 564 & 631 & 797 \\
\hline Foreign investment per capita, EUR & 316 & 908 & 2174 \\
\hline ERDF, ESF, CF funding per capita, EUR & 1811 & 2027 & 976 \\
\hline Local government equalisation funding per capita, EUR & 1113 & 604 & -397 \\
\hline Managed UAA per capita, ha & 3.53 & 2.59 & 0.86 \\
\hline Land quality, points & 37 & 38 & 35 \\
\hline Forest area per capita, ha & 2.74 & 5.71 & 1.28 \\
\hline Amount of EAGF, EAFRD, EFF funding per capita, EUR & 3178 & 2436 & 813 \\
\hline \multicolumn{4}{|l|}{ Turnover of top 20 enterprises: } \\
\hline Total turnover per capita, EUR & 4440 & 7419 & 17672 \\
\hline Primary production, turnover per capita, EUR & 1603 & 1242 & 418 \\
\hline Secondary production, turnover per capita, EUR & 1244 & 2753 & 3701 \\
\hline Services sector, turnover per capita, EUR & 1767 & 3607 & 13809 \\
\hline Total support payments paid by the RSS, EUR & 5600 & 4981 & 4547 \\
\hline Area-based support payments, EUR & 3580 & 3057 & 2704 \\
\hline
\end{tabular}

Source: authors' calculations based on LLU, 2014, 2015, CSB, 2016a, 2016b, SRDA, 2016, Riga, 2016, RSS, 2016a, 2016b, 2016c, 2016d, SLS, 2014, LV, 2013, Lursoft, 2016. 
have better performed with regard to absorbing EU funding, the funding related to agriculture and rural development in particular. The greatest size of managed UAA per capita and the greatest amount of RSS-administered support payments, including areabased ones, indicated the key income sources for their residents. In the municipalities where the population decreased by less than $20 \%$, the situation was average. The municipalities attracted the greatest amounts of ERDF, ESF, CF funding per capita as well as had the largest forest areas per capita.

After grouping the municipalities by change in population size in 2014 compared with 2004, one can conclude that an increase in the population and positive economic performance indicators were interrelated. Besides, not always a large population was the most essential factor - it was rather the location of the municipality. However, there are a number of discussible aspects - large retail and wholesale trade enterprises were located in Pieriga municipalities, which theoretically positively influenced the local territories and their economic situation. Statistical data and calculations show better performance in terms of enterprise turnover and wages and salaries, but it does not always reflect the real situation. A number of enterprises, which were usually international companies and did not do their business in the entire territory of Latvia, were registered, because of various reasons, in Pieriga municipalities; therefore, one cannot assert that entrepreneurial development was the merit of a particular municipality.

\section{Analysis of the municipalities in terms of revenue} and income and change in the revenue and income

The second group of indicators showing trends in the development of the municipalities involves PIT revenue; most of the PIT revenues $(80 \%)$ are paid to local governments and are their key source of their tax revenues. The amount of PIT revenue per capita reflects the income level of residents and, consequently, the life quality of the residents. Grouping the municipalities by per-capital amount of PIT revenue paid to the local government resulted in four groups - most municipalities (43) belonged to the group with a per-capita amount of PIT revenue in the range of EUR 281-380 in 2013 (Table 3).

An analysis of the indicators for the groups of municipalities revealed a number of explicit trends. The municipalities with a greater per-capita amount of PIT revenue had larger populations that had increased since 2004, shorter distances to Riga (all the boundary municipalities of Riga belonged to the group with the highest PIT indicators), a higher average monthly wage and salary and considerably greater investments. The municipalities did not receive funds from the Local Government Equalisation Fund - they made contributions to the Fund. However, their primary production resources were smaller than those of other groups, including the managed UAA, the quality of land and the forest area, which resulted in a very low turnover of primary sector enterprises. The amounts of support payments disbursed by the RSS, including area-based payments, were average, while relatively small amounts were attracted from EU programmes for agriculture and rural development. In contrast, the municipalities with a small per-capita amount of PIT revenue had diametrically opposite indicator values, indicating an unfavourable economic situation where primary production prevailed - with large land and forest resources and large per-capita amounts of RSSadministered support payments.

The PIT is one of the most significant income sources for local governments and an analysis of the data showed that the smaller the per-capita amount of PIT revenue is collected by a municipality, the larger subsidies the municipality receives from the Local Government Equalisation Fund. This indicates instability and potential stagnation. There are sharp disparities in PIT revenue across the municipalities in relation to the distance to Riga - the further the municipality is located away from Riga, the smaller is the per-capita amount of PIT revenue, which shows the positive effect of the capital city.

In analysing the situation, it is important to examine not only the current situation, based on the most recent data available, but also the trend observed in a longer term. Changes in the amounts of PIT revenue paid to the local government in 2013 compared with 2004 were analysed in order to identify how the municipalities developed in the 10 year period (Table 4 ).

Grouping the municipalities by pace of increase in PIT revenue does not allow definitely asserting that a faster pace of increase is positively related to the highest values of economic indicators and to positive changes caused by the other influencing factors. An explicit trend was observed in relation to increases in the population, the average monthly wage and salary, the per-capita amount of PIT revenue in 2013, and the total turnover of enterprises per capita - the values of the indicators increased if a faster pace of increase in PIT revenue was observed, whereas the amount of subsidies from the Local Government Equalisation Fund decreased.

One cannot definitely assert that more intensive development in terms of increase in PIT revenue was observed in the municipalities that are located the closest to Riga or had the largest populations. This means that in a long-term, economic growth has been influenced by other factors as well. There is an interesting aspect related to investment - as the pace of increase in PIT revenue accelerates, 


\section{Characteristics of the situation in the municipalities grouped by per-capita amount of PIT revenue in 2013}

\begin{tabular}{|c|c|c|c|c|}
\hline \multirow{2}{*}{ Indicators } & \multicolumn{4}{|c|}{ Amount of PIT revenue per capita, EUR } \\
\hline & $\leq 280$ & $281-380$ & $381-480$ & $\geq 481$ \\
\hline Number of municipalities in a group & 18 & 43 & 26 & 23 \\
\hline Population & 7019 & 7414 & 10129 & 11724 \\
\hline Change in the population in 10 years & 0.77 & 0.78 & 0.84 & 1.46 \\
\hline Distance to Riga (average for the group), $\mathrm{km}$ & 234 & 147 & 110 & 40 \\
\hline Boundary municipalities of Riga & 0 & 0 & 0 & 11 \\
\hline Pieriga municipalities & 0 & 0 & 4 & 20 \\
\hline Boundary municipalities of republican cities & 3 & 5 & 5 & 9 \\
\hline Increase in PIT revenue per capita, \% & 2.23 & 1.63 & 1.66 & 2.45 \\
\hline Average monthly wage and salary, EUR & 532 & 583 & 644 & 769 \\
\hline Foreign investment per capita, EUR & 107 & 538 & 998 & 1854 \\
\hline ERDF, ESF, CF funding per capita, EUR & 909 & 2188 & 1787 & 1591 \\
\hline Local government equalisation funding per capita, EUR & 1572 & 931 & 494 & -341 \\
\hline Managed UAA per capita, ha & 4.67 & 3.09 & 2.61 & 0.66 \\
\hline Land quality, points & 37 & 38 & 39 & 36 \\
\hline Forest area per capita, ha & 5,43 & 5,02 & 3,92 & 1,34 \\
\hline Amount of EAGF, EAFRD, EFF funding per capita, EUR & 3785 & 3012 & 2518 & 521 \\
\hline \multicolumn{5}{|l|}{ Turnover of top 20 enterprises: } \\
\hline Total turnover per capita, EUR & 3207 & 5633 & 7457 & 15689 \\
\hline Primary production, turnover per capita, EUR & 1198 & 1768 & 1261 & 398 \\
\hline Secondary production, turnover per capita, EUR & 731 & 1693 & 3110 & 3441 \\
\hline Services sector, turnover per capita, EUR & 1443 & 2367 & 3219 & 12124 \\
\hline Total support payments paid by the RSS, EUR & 6029 & 4792 & 5047 & 5420 \\
\hline Area-based support payments, EUR & 3831 & 3005 & 3086 & 3353 \\
\hline
\end{tabular}

Source: authors' calculations based on LLU, 2014, 2015, CSB, 2016a, 2016b, SRDA, 2016, Riga, 2016, RSS, 2016a, 2016b, 2016c, 2016d, SLS, 2014, LV, 2013, Lursoft, 2016.

the amount of investment considerably decreases, except for the fourth group of municipalities with the fastest pace of increase in PIT revenue where the amount of investment was the greatest. A similar situation was observed in relation to the amount of attracted EAGF, EAFRD, EFF funding. In contrast, the values of other indicators varied across the groups of municipalities, showing no explicit increase or decrease trends. For example, the group of municipalities with the fastest pace of increase in PIT revenue had small amounts of land and forest resources, whereas the third group comprising the municipalities with a medium fast pace of increase in PIT revenue had large amounts of the mentioned resources. This indicates that economic development, the dependent indicator of which is the pace of increase in PIT revenue, may not be definitely explained by means of the indicators used.

In addition, more detailed data should be analysed, employing also subjective indicators and the human factor, e.g. the professionalism of local government officials of a particular municipality, the attractiveness of a territory in the eyes of its residents, government policies on, for example, the location and reorganisation of health care and educational institutions.

Within a regional economy, we can increase prosperity (i.e., generate more outputs or wealth) in two ways: 1) first, we can grow the economy through increasing inputs - either by attracting new resources from outside the region (such as human capital, businesses and investments) or by more fully deploying existing resources (underemployed labour, underdeveloped real estate, etc.); 2) second, we can increase the productivity and efficiency of the regional economy (increase outputs per unit of input) - by improving efficiency of market operations and governance; enhancing the interactions and synergies between different kinds of economic activity; and improving how the assets of the economy are 
Table 4

Characteristics of the situation in the municipalities grouped by change in the amount of PIT revenue in the period $2004-2013$

\begin{tabular}{|c|c|c|c|c|}
\hline \multirow{2}{*}{ Indicators } & \multicolumn{4}{|c|}{ Increase in PIT revenue, $\%$} \\
\hline & $\leq 150$ & $151-200$ & $201-250$ & $\geq 251$ \\
\hline Number of municipalities in a group & 37 & 45 & 16 & 12 \\
\hline Population & 10188 & 8971 & 6770 & 7431 \\
\hline Change in the population in 10 years & 0.78 & 0.95 & 1.00 & 1.26 \\
\hline Distance to Riga (average for the group), $\mathrm{km}$ & 150 & 137 & 92 & 94 \\
\hline Boundary municipalities of Riga & 0 & 3 & 3 & 5 \\
\hline Pieriga municipalities & 3 & 8 & 6 & 7 \\
\hline Boundary municipalities of republican cities & 0 & 10 & 5 & 7 \\
\hline PIT revenue per capita, EUR & 355 & 371 & 436 & 567 \\
\hline Average monthly wage and salary, EUR & 590 & 622 & 665 & 716 \\
\hline Foreign investment per capita, EUR & 1075 & 581 & 849 & 1179 \\
\hline ERDF, ESF, CF funding per capita, EUR & 2020 & 1853 & 1037 & 1564 \\
\hline Local government equalisation funding per capita, EUR & 569 & 820 & 755 & 275 \\
\hline Managed UAA per capita, ha & 2.18 & 3.15 & 3.37 & 1.95 \\
\hline Land quality, points & 37 & 38 & 37 & 36 \\
\hline Forest area per capita, ha & 4.30 & 4.05 & 4.41 & 2.84 \\
\hline Amount of EAGF, EAFRD, EFF funding per capita, EUR & 2251 & 2711 & 2875 & 1987 \\
\hline \multicolumn{5}{|l|}{ Turnover of top 20 enterprises: } \\
\hline Total turnover per capita, EUR & 5496 & 6188 & 11176 & 16169 \\
\hline Primary production, turnover per capita, EUR & 811 & 1605 & 1591 & 986 \\
\hline Secondary production, turnover per capita, EUR & 1961 & 2100 & 2072 & 3813 \\
\hline Services sector, turnover per capita, EUR & 3008 & 2608 & 7715 & 11516 \\
\hline Total support payments paid by the RSS, EUR & 5736 & 4802 & 5624 & 4341 \\
\hline Area-based support payments, EUR & 3778 & 2860 & 3437 & 2670 \\
\hline
\end{tabular}

Source: authors' calculations based on LLU, 2014, 2015, CSB, 2016a, 2016b, SRDA, 2016, Riga, 2016, RSS, 2016a, 2016b, 2016c, 2016d, SLS, 2014, LV, 2013, Lursoft, 2016.

organized and deployed spatially (George Washington Institute..., 2011).

\section{Conclusions}

1. The municipalities of Latvia are diverse in terms of population size. The municipalities with larger populations have higher resident incomes and a higher turnover of enterprises. The best performance indicators were demonstrated by the municipalities with a population in the range of $8-12$ thousand. Such municipalities had the highest investment level, larger enterprises in terms of turnover and a lower proportion of public sector employees. In contrast, the prevalence of primary production and ineffective land management were specific to the municipalities with small populations.

2. In the period $2004-2014$ in Latvia, the population decreased by more than $20 \%$ in 49 municipalities ( $45 \%$ of the total). Such municipalities are located far away from the capital city and low economic performance indicators and the prevalence of the primary sector were typical of them. The population increased in 14 municipalities that are situated close to Riga and had active entrepreneurship and high economic performance indicators.

3. The municipalities with the highest tax revenue collected had larger populations that increased in the period of analysis, and such municipalities are located in the vicinity of Riga and high economic performance indicators were characteristic of them. In contrast, the municipalities with small per-capita amounts of PIT revenue had diametrically opposite indicator values, indicating an unfavourable economic situation where primary production prevailed - with large land and forest resources and large per-capita amounts of RSSadministered support payments.

4. The PIT is one of the most significant income sources for local governments, and the smaller the 
per-capita amount of PIT revenue is collected by a municipality, the larger subsidies the municipality receives from the Local Government Equalisation Fund. Grouping the municipalities by pace of increase in PIT revenue does not allow definitely asserting that a faster pace of increase is positively related to the highest values of economic performance indicators and to positive changes caused by the other influencing factors, as in a long-term economic growth has been influenced by other factors as well.

\section{Acknowledgements}

The research was promoted with the support of the JSC 'Latvian State Forests', Contract No. 5.5.5.1._001q_101_14_42.

\section{References}

1. Administratīvo teritoriju un apdzīvoto vietu likums (Law On Administrative Territories and Populated Areas) (2008). Published by Latvijas Vēstnesis, No. 202 (3986), 30.12.2008., 'Ziṇotājs', No. 3, 12.02.2009. (in Latvian).

2. Ambrosio-Albalá, M., \& Bastiaensen, J. (2010). The New Territorial Paradigm of Rural Development: Theoretical Foundations from Systems and Institutional Theories. Institute of Development Policy and Management, Discussion Paper /2010.02, May 2010, 68 p.

3. Bank of Latvia (LB) (2013). Latvijas Bankas noteiktie valūtu kursi 31.12.2013 (Exchange rates set by the Bank of Latvia until 31.12.2013). Retrieved November 21, 2016, from: https://www.bank.lv/statistika/ valutu-kursi/vesturiskie-kursi-lidz-2013-gada-31-decembrim. (in Latvian).

4. Bellù, L.G. (2011). Development and Development Paradigms. A (Reasoned) Review of Prevailing Visions" EASYpol Resources for Policy Making. Retrieved November 28, 2016, from: http://www.fao. org/docs/up/easypol/882/defining_development_paradigms_102en.pdf.

5. Boisier, S. (2005). Is there Room for Local Development in a Globalized World? Cepal Review 86, August 2005. Retrieved November 23, 2016, from: http://repositorio.cepal.org/bitstream/ handle/11362/11091/86045060I_en.pdf?sequence $=1$.

6. Central Statistical Bureau (CSB) (2016a). ISG12. Pastāvīgo iedzīvotāju skaits statistiskajos reǵionos, republikas pilsētās un novados gada sakumā (Resident population by statistical region, city and county). Retrieved November 22, 2016, from: http://data.csb.gov.lv/pxweb/lv/Sociala/Sociala_ikgad_ iedz_ iedzskaits/IS0120.px/?rxid=cdcb978c-22b0-416a-aacc-aa650d3e2ce0. (in Latvian).

7. Central Statistical Bureau (CSB) (2016b). DSG07. Strādājošo mēneša vidējā darba samaksa republikas pilsētās un novados (euro) (Average monthly wages and salaries in cities under state jurisdiction and counties (in euro)). Retrieved November 22, 2016, from: http://data.csb.gov.lv/pxweb/lv/Sociala/Sociala ikgad_dsamaksa/DS0070_euro.px/?rxid=cdcb978c-22b0-416a-aacc-aa650d3e2ce0. (in Latvian).

8. Dower, M. (2013). Rural Development in the New Paradigm. In: New Paradigm in Action - on Successful Partnerships. Ministry of Regional Development, Warsaw, pp. 30 - 50.

9. Dunmade, I. (2014). Sustainability Issues in Rural-Urban Partnerships: A Study on Regional and Intermunicipal Collaborations between some Southern Alberta Municipalities. Environment and Ecology Research 2(1), pp. $1-7$.

10. ECORYS Nederland BV (2010). Study on Employment, Growth and Innovation in Rural Areas (SEGIRA). Rotterdam, 8 December 2010, 285 p.

11. Eppler, U., Fritsche, U.R., \& Laaks, S. (2015). Urban-Rural Linkages and Global Sustainable Land Use. Resource-Efficient Land Use -Towards A Global Sustainable Land Use Standard BMU-UBA Project No. FKZ 371193101, Berlin.

12. ESPON (2013). EDORA European Development Opportunities for Rural Areas. Applied Research 2013/1/2. Draft Final Report: Version 1, 30/04/2010. Part A and Part BESPON \& UHI Millennium Institute, $81 \mathrm{p}$.

13. European Commission (2011). Rural development report. 3.1. Importance of rural areas. Retrieved November 22, 2016, from: http://ec.europa.eu/agriculture/sites/agriculture/files/statistics/ruraldevelopment/2011/ch31_en.pdf.

14. George Washington Institute of Public Policy and RW Ventures, LLC (2011). Implementing Regionalism: Connecting Emerging Theory and Practice to Inform Economic Development, November 2011, 248 p.

15. LLU (2014). Gala atskaite par projektu 'Zemes ekonomiski efektīva, ilgtspējīga un produktīva izmantošana lauksaimniecības un mežsaimniecības produkcijas ražošanai’. 2014. gada janvāris (Final report on the project "Economically Efficient, Sustainable and Productive Use of Land for the Production of Agricultural and Forestry Products. January 2014), p. 260. 
16. LLU (2015). Pētījuma 'Dažādu zemes apsaimniekošanas modeḷu sociāli ekonomiskais novērtējums’ III daḷa Teritoriju attīstību veicinošo faktoru noteikšana. 2015. gada decembris (Research 'Socio-economic Assessment of Various Land Management Models' Part III Identification of Factors Promoting Territorial Development. December 2015), p. 70. Retrieved November 24, 2016, http: www.lvm.lv/petijumi-unpublikacijas/dazadu-zemes-apsaimniekosanas-modelu-sociali-ekonomiskais-novertejums. (in Latvian).

17. Lursoft (2016). Lursoft statistika (Lursoft statistics). Retrieved November 21, 2016, from: http://www. lursoft.lv/lursoft-statistika/. (in Latvian).

18. Rīga (2016). Attālumi līdz citām pilsētām (Riga. Distance to other Cities). Retrieved November 21, 2016, from: http:/www.city-info.net/lv/terminal-11-11/noderiga-informacija-156/attalumi-lidz-citampilsetam-3934. (in Latvian).

19. Rural Support Service (RSS) (2016a). Platību maksājumi (Area Payments). Retrieved November 20, 2016, from: http: www.lad.gov.lv/lv/statistika/platibu-maksajumi/. (in Latvian).

20. Rural Support Service (RSS) (2016b). Operatīva informācija par apmaksātajiem ELFLA (2007 - 2013 planošanas periods) projektiem sadalījumā pa LAD struktūrvienībām, EUR (Operational information on funded EAFRD projects (programming period 2007 - 2013) by RSS department, EUR). Retrieved November 20, 2016, from: http://www.lad.gov.lv/files/elfla_2007_2013.pdf. (in Latvian).

21. Rural Support Service (RSS) (2016c). Operatīva informācija par apmaksātajiem EZF projektiem sadalījumā pa LAD struktūrvienībām līdz 31.12.2013., LVL (Operational information on funded EFF projects by RSS department until 31.12.2013, LVL). Retrieved November 20, 2016, from: http://www.lad.gov.lv/files/ elfla_2007_2013.pdf. (in Latvian).

22. Rural Support Service (RSS) (2016d). Lauku reǵistrs. Lauku reǵistra ǵeogrāfiskās informācijas sistēmas datu bāze (Rural Register. Database of the geographic information system of the Register of Fields). Unpublished resource. Retrieved November 20, 2016, from: http:/www.lad.gov.lv/lv/atbalsta-veidi/ platibu-maksajumi/lauku-registrs-un-karte/LAD. (in Latvian).

23. State Land Service (SLS) (2014). VZD pārskats Latvijas Republikas administratīvo teritoriju un teritoriālo vienību zemes datu bāze uz 2013. gada 1. janvāri (SLS Report Database for the Land of Administrative Territories and Territorial Units of the Republic of Latvia as of 01.01.2013). (in Latvian).

24. State Regional Development Agency (SRDA) (2016). Reǵionālās attīstības indikatoru modulis Raim.gov. lv. (Regional Development Indicator Module RDIM.gov.lv) Retrieved November 22, 2016, from: http:// raim.gov.lv/cms/tiki-index.php?page=Datu+atlase. (in Latvian).

25. Vītola, A. (2013). Lauku attīstības iespējas radošās ekonomikas laikmetā. (Development of the Rural Areas in the Age of Creative Economy). Retrieved January 19, 2017, from: http://du.lv/wp-content/ uploads/2013/10/17Vitola.pdf. (in Latvian).

26. Zemkopības ministrija (2016). Latvia - Rural Development Programme (National) 2014 - 2020. Riga, 589 p. 